\title{
The Application of Total Cost of Ownership Method to Automotive Industry
}

\author{
Patrik Richnák $^{1 *}$, Klaudia Gubová ${ }^{1}$ and Janka Fabianová ${ }^{1}$ \\ ${ }^{1}$ University of Economics in Bratislava, Department of Production Management and Logistics, \\ Dolnozemská cesta 1, Bratislava, Slovak Republic; Email: patrik.richnak@euba.sk, \\ klaudia.gubova@euba.sk,fabianovajanka6@gmail.com
}

\section{*Corresponding Author: Patrik Richnák}

Received: 18 October 2020; Revised: 26 October 2020; Accepted: 29 October 2020; Published: 30 November 2020

\begin{abstract}
Transport currently has the largest share of air pollution, among all sectors. Increasing air pollution caused by conventional cars brings an opportunity to develop electric cars, which are a green alternative in transport. The main aim of the article was to explain the terms related to electromobility through the literature and then to examine the total cost of electric cars and conventional cars on the example of selected four models. The comparison was made on the example of the best-selling four selected models: electric car, hybrid car, plug-in hybrid car and standard petrol car. The methods were used in the elaboration of the article: analysis, synthesis, induction, deduction and comparison. We used the Total Cost of Ownership (TCO) method to process the results. The intention of the article was to point out the lower total cost of ownership for electric cars and to confirm the fact that electric cars are a profitable investment in the future.
\end{abstract}

Keywords: Electromobility, electric car, e-mobility, total cost of ownership

\section{Introduction}

Nowadays, electromobility is emerging as the innovative trend in the field of transport. In particular, in the European framework, one of the goals of the European Commission is to eliminate conventional internal combustion engine vehicles (ICEVs) in cities by 2050, overcoming the issues of emissions, urban air quality and noise pollution and guaranteeing a better quality of life and health for European citizens [1]. The market share in electric vehicles (EV) is increasing. This trend is likely to continue due to the increased interest in reducing CO2 emissions [2].

The automotive industry is gradually shifting from traditional cars powered by internal combustion engines (ICE) to less carbon-intensive drive technologies, including fully batteryelectric vehicles (BEV) and hybrid-electric cars. The latter combine electric engines with smaller combustion engines. Different degrees of hybridization exist [3]. 
Electromobility indisputably belongs to the automotive industry. However it also belongs to the clean tech industry because it involves low-carbon vehicles powered by electrical energetic sources. This technological evolution implies a disruptive break from the traditional principle of a vehicle with an internal combustion engine (ICE), because the technological heart of the product is no longer solely the engine which defines the power of the vehicle [4].

Nowadays, most of the major automobile manufacturers have introduced their own electric vehicles (EVs) and/or hybrid electric vehicles (HEVs). Compared with conventional ICE (internal combustion engine)-propelled vehicles, EVs demonstrate much higher energy efficiency and zero tailpipe emission due to the employment of electric motors [5]. While operating fully electric, electric vehicles are free of exhaust gas emissions and thus eliminate local pollution. This means that emissions that are harmful to natural environment or health are not released from vehicles, the latter of which is of great importance especially in urban environments with much traffic and large populations [6].

Electromobility and EVs may become a key factor of sustainable and environmentally-friendly mobility in the future [7], contributing to the reduction of air pollution and greenhouse gas emissions [8]. Vehicles with electric drive systems are discussed as an option to reduce transport's emissions in the political and scientific context. Their main advantages are a higher efficiency of electric motors compared to internal combustion engines (ICEs), the absence of local pollutants emissions, reduced noise pollution and the possible reduction of GHG emissions compared to ICEs using low-carbon electricity generation. Current disadvantages comprise high overall investment costs, long battery charging times, low driving ranges and limited public and private charging infrastructure [9]. The introduction of electromobility will stimulate completely new approaches and tools for charging station management, as well as electrical energy management and power balancing systems. Also, new customer management applications, billing services and mobile navigation applications for drivers, together with seat reservation, and loyalty programs for passengers have to be developed [10].

New powertrain technologies, such as Hybrid Electric Vehicles, have a price premium which can often be offset by lower running costs. Total Cost of Ownership combines these purchase and operating expenses to identify the most economical choice of vehicle [11].

TCO is a purchasing tool and philosophy, which is aimed at understanding the true cost of buying a particular good or service from a particular supplier. TCO is a useful calculation for consumers and firms alike to assess the direct and indirect cost associated with a purchase [12]. The TCO method allows consumers to directly compare all costs that are associated with the ownership of a product during its useful life [13]. A TCO analysis covers all costs occurring over the lifetime of the object. For a vehicle, this includes one-time costs like the purchase costs, but also recurring 
expenses like fuel and maintenance cost [14]. TCO models might have two cost components: one including the costs borne by the vehicle user (the consumer-oriented TCO), and one including the costs borne by society, as for example air and noise pollution (the society-oriented TCO) [15]. The TCO can be separated into capital costs (the cost of purchasing vehicles) and operational costs (the cost of using vehicles). Fuel costs typically comprise a significant part of overall operational costs. This is especially true for countries where fuel taxes are high. Increased energy efficiency can thus reduce the TCO [16].

Literature reveals many TCO studies on electric vehicles, especially since 2008, when several car manufacturers launched their plans of mass production of electric vehicles. TCO analyses can be divided into two main categories: consumer oriented studies and society oriented studies. In the first group, the consumer point of view is considered. The costs that are perceived by the consumers are incorporated and different vehicle technologies are compared. Society oriented TCO studies have a broader scope: next to the consumer costs, externalities (emissions, noise...) and the associated external costs of EVs are included [17].

\section{Data and Methods}

The main aim of the article was to explain the terms related to electromobility through the literature and then to examine the total cost of electric cars and conventional cars. The comparison was made on the example of the best-selling four selected models: electric car, hybrid car, plug-in hybrid car and standard petrol car. The reason for selecting the given cars was because we wanted to point out the costs of the best-selling cars of individual brands. Of course, if we choose a different type of cars, the results would be divergent, but not significantly different, they would be similar.

The methods were used in the elaboration of the article: analysis, synthesis, induction, deduction and comparison. We used the Total Cost of Ownership (TCO) method to process the Results. This method is classified as a mathematical method. The TCO method expresses the complex of costs associated with the purchase and operation of individual cars. We calculated the costs of four selected cars. The total costs included the purchase price, grant, taxes, fees, maintenance costs and fuel costs. The individual costs were processed and then we interpreted the results through a graphical representation in the form of tables and figures.

\section{Results}

Total cost of ownership (TCO) of cars, express the complex costs associated with the investment and operation of cars. They include the purchase price and expenses related to car ownership. In practice, the TCO method serves to express the total cost over its lifetime and prevents distortion of the facts. For example, with a low purchase price, operating costs can be very high or have a short 
lifespan and need to be changed frequently. Total costs through TCO can reveal that a low purchase price does not always mean low costs throughout the life cycle. The disadvantage of the TCO method is that it does not take into account the value of money and evaluates the investment only in terms of costs.

Automotive enterprises are constantly investing in the development of electric cars. Most major automotive enterprises offer or will offer electric car models in the near future. The article compares four best-selling models in the analysis of total costs: electric car, hybrid car, plug-in hybrid car and standard petrol car. All four car models represent middle class family cars.

One of the best-selling electric cars in Slovakia is the Nissan LEAF, which also became the best-selling electric car in Europe in 2018. The Nissan LEAF has few moving parts, which means that it has lower maintenance costs and electric drive ensures minimal operating costs. Its price ranges from 35,630 € [18]. The Ministry of Economy of the Slovak Republic, in cooperation with the Slovak Innovation and Energy Agency, provided the grant for electric cars in the amount of $8,000 €$. Following the application of the grant, the purchase price of the Nissan LEAF electric car will be significantly reduced.

Hyundai IONIQ is a car that offers everyday comfort and versatility. The car has a pure electric range of more than $52 \mathrm{~km}$. The car produces low $\mathrm{CO}_{2}$ emissions of only $32 \mathrm{~g} / \mathrm{km}$. The car has a simple switch, it switches to hybrid mode with one touch. At present, its price starts at $30,490 €$ [19]. The state provides a grant of 5,000€ for the Hyundai IONIQ Plug-in Hybrid Car.

Toyota CR-H is a car combining an internal combustion engine and an electric motor. The car has an intelligent fourth-generation hybrid system that delivers fuel savings. The accumulators make it possible to recover more energy, which guarantees a longer and quieter ride in electric mode. The Toyota CR-H is able to run on short distances with lower emissions. The price of the car starts from $24,490 €[20]$. The Toyota CR-H model does not meet the criteria for obtaining a government grant.

The Škoda Octavia is manufactured in the Czech Republic by Škoda. The Škoda Octavia is one of the middle-class models and is the best-selling model. The car also offers an excellent quality/price ratio. The Škoda Octavia has various variants of models with a wide range of equipment. The basic price ranges from $14,990 €$ to $32,140 €[21]$.

Among the fixed acquisition costs, we include the purchase price, motor car tax and registration tax. An overview of the list prices of the mentioned cars, including discounts, grant, taxes and insurance, is given in Table 1. 
Table 1 Overview of prices and fees of the examined models. Source: authors

\begin{tabular}{cccccc}
\hline The car & $\begin{array}{c}\text { Price } \\
{[\text { EUR] }}\end{array}$ & $\begin{array}{c}\text { Grant } \\
{[\text { EUR] }}\end{array}$ & $\begin{array}{c}\text { Registration tax } \\
{[\text { EUR] }}\end{array}$ & $\begin{array}{c}\text { Motor-car tax } \\
{[\text { EUR] }}\end{array}$ & $\begin{array}{c}\mathrm{CO}_{2} \text { emissions } \\
{[\mathrm{kg}]}\end{array}$ \\
\hline Nissan Leaf & $35,630.00$ & $8,000.00$ & 33.00 & - & $9,447.55$ \\
\hline $\begin{array}{c}\text { Hyundai } \\
\text { Ioniq }\end{array}$ & $30,490.00$ & $5,000.00$ & 55.00 & 592.00 & $9,480.42$ \\
\hline Toyota CH-R & $24,490.00$ & - & 55.00 & 592.00 & $14,100.00$ \\
\hline $\begin{array}{c}\text { Škoda } \\
\text { Octavia }\end{array}$ & $23,590.00$ & - & 574.00 & $1,184.00$ & $18,000.00$ \\
\hline
\end{tabular}

In Figure 1 we can see a graphical representation of input costs from Table 1. The acquisition costs included the purchase price of the car, grant, registration tax and motor-car tax. On the right axis you can see the amount of $\mathrm{CO}_{2}$ emissions produced by each type of car. Total $\mathrm{CO}_{2}$ emissions included emissions from production and operational emissions. The government grant of $8,000 €$ was deducted from the purchase price of the Nissan Leaf electric car. The government grant of 5,000 € was deducted for the Hyundai Ioniq. We can see from Figure 1 that the purchase price of an electric car is higher than the price of a conventional car, despite the provided the government grant.

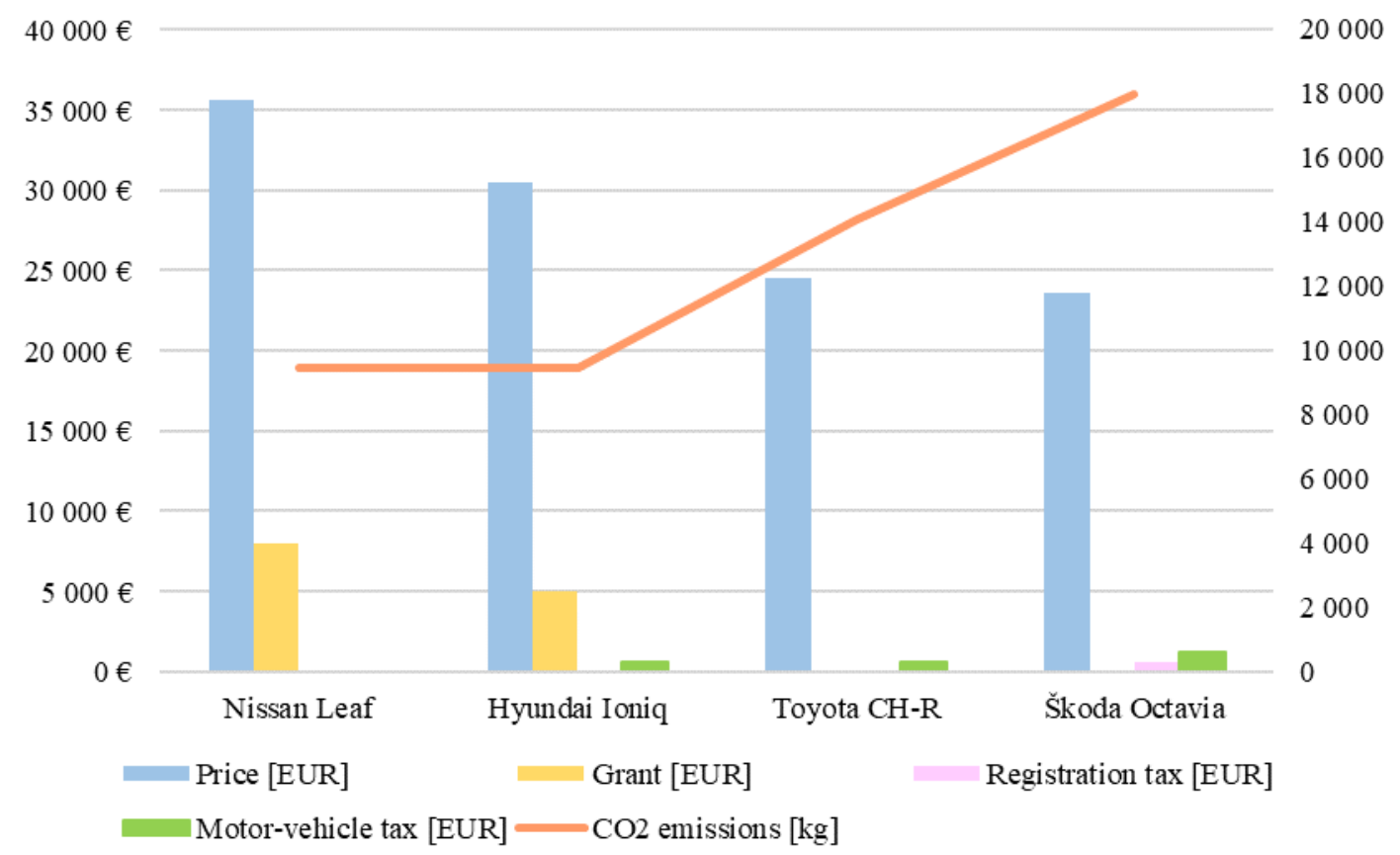

Fig. 1 Acquisition costs. Source: authors

Fuel costs for an electric car lower than for conventional cars. The advantage of electric cars over cars with an internal combustion engine is that they can also be charged at home. The amount of fuel costs depends on the method of charging, either through public charging or domestic charging. The most well-known operators of charging stations in Slovakia are Green Way and ZSE. 
Enterprises offer various service packages. It is necessary to establish access cards for individual enterprises. Both operators also have mobile applications where the customer can find the location, occupancy of chargers and make a reservation for charging. The application also offers customers an overview of charging and account status. Data on charging stations and prices are available on their website. Table 2 provides an overview of the programs offered by individual enterprises in comparison with the price of home charging.

Table 2 Overview of charging prices for electric cars. Source: authors

\begin{tabular}{ccccc}
\hline Operator & $\begin{array}{c}\text { Service } \\
\text { program }\end{array}$ & $\begin{array}{c}\text { Monthly } \\
\text { fee }\end{array}$ & $\begin{array}{c}\text { DC charging } \\
{[€ / \mathrm{kWh}]}\end{array}$ & $\begin{array}{c}\text { AC charging } \\
{[€ / \mathrm{kWh}]}\end{array}$ \\
\hline \multirow{3}{*}{ Green Way } & $\begin{array}{c}\text { Disposable } \\
\text { charging }\end{array}$ & $0.00 €$ & $0.56 €$ & $0.25 €$ \\
\cline { 2 - 5 } & $\begin{array}{c}\text { Energy } \\
\text { Standard }\end{array}$ & $0.00 €$ & $0.49 €$ & $0.25 €$ \\
\cline { 2 - 5 } & Energy Plus & $14.90 €$ & $0.34 €$ & $0.25 €$ \\
\cline { 2 - 5 } & Energy Max & $24.90 €$ & $0.29 €$ & $0.25 €$ \\
\hline \multirow{3}{*}{ ZSE } & Guest & $0.00 €$ & $0.49 €$ & $0.29 €$ \\
\cline { 2 - 5 } & Eco & $0.00 €$ & $0.39 €$ & $0.19 €$ \\
\cline { 2 - 5 } & Partner & $9.00 €$ & $0.29 €$ & $0.15 €$ \\
\hline Home charging & Flat & $69.00 €$ & $0.00 €$ & $0.00 €$ \\
\hline
\end{tabular}

Table 3 shows fuel prices, consumption and repair and maintenance costs for individual cars. Average petrol prices at the beginning of 2020 in the Slovak Republic were around $1.35 € / 1$ [22]. The average price of charging electric cars, which will be used in the calculations, is set at the level of $0.15 € / \mathrm{kWh}$. This price was created on the assumption that the customer charges his electric car with domestic charging to $70 \%$ at the price of $0.09 € / \mathrm{kWh}$ and the remaining $30 \%$ is charged on the public charger of ZSE with the Partner program package in the amount of $0.29 € / \mathrm{kWh}$. Data on maintenance costs were obtained from XY, Ltd, which uses individual cars for business purposes. Maintenance costs included, for example, tire changes, brake changes and other one-off costs associated with the maintenance of individual cars. The maintenance costs of electric cars did not include the replacement of the battery, as it is considered that it will last for the entire life of the electric car. 
Table 3 Operating costs. Source: authors

\begin{tabular}{ccccccc}
\hline The car & Fuel & Consumption & Unit & $\begin{array}{c}\text { Price } \\
{[\mathrm{EUR}]}\end{array}$ & $\begin{array}{c}\text { Consumption for } \\
10,000 \mathrm{~km} \\
{[\mathrm{EUR}]}\end{array}$ & $\begin{array}{c}\text { Repairs and } \\
\text { maintenance for } \\
10,000 \mathrm{~km} \text { [EUR] }\end{array}$ \\
\hline $\begin{array}{c}\text { Nissan } \\
\text { Leaf }\end{array}$ & elektric & 171.00 & $\mathrm{Wh} / \mathrm{km}$ & 0.15 & 256.50 & 50.00 \\
\hline $\begin{array}{c}\text { Hyundai } \\
\text { Ioniq }\end{array}$ & petrol & 1.10 & $\begin{array}{c}1 / 100 \\
\mathrm{~km}\end{array}$ & 1.35 & 268.89 & 150.00 \\
\hline $\begin{array}{c}\text { Toyota } \\
\text { CH-R }\end{array}$ & $\begin{array}{c}\text { hybrid } \\
(\mathrm{e}+\mathrm{g})\end{array}$ & 3.80 & $\begin{array}{c}1 / 100 \\
\mathrm{~km}\end{array}$ & 1.35 & 513.00 & 150.00 \\
\hline $\begin{array}{c}\text { Škoda } \\
\text { Octavia }\end{array}$ & petrol & 5.80 & $\begin{array}{c}1 / 100 \\
\mathrm{~km}\end{array}$ & 1.35 & 783.00 & 150.00 \\
\hline
\end{tabular}

Total Cost of Ownership (TCO) expresses the complex cost associated with investing in and operating the car. TCO include cost and ownership costs such as operating costs and fuel costs. The total cost of electric cars with increasing mileage is becoming more cost-effective. Despite their higher purchase price, the electric car is becoming the most economically advantageous alternative. Repairs and maintenance, which are incomparably higher in conventional cars with internal combustion engines, also play an important role. Electric cars do not require oil change or other maintenance related to internal combustion engines, as they have fewer mechanical components. Table 4 shows the results of the total cost calculations for mileage.

Table 4 Results of TCO calculations. Source: authors

\begin{tabular}{lccccccccc}
\hline $\begin{array}{l}\text { Mileage in } \\
\text { thousands }\end{array}$ & 0 & 30 & 60 & 90 & 120 & 150 & 180 & 210 & 240 \\
\hline Škoda Octavia & 25.35 & 27.34 & 29.34 & 31.34 & 33.33 & 35.33 & 37.33 & 39.32 & 41.32 \\
\hline Toyota CH-R & 25.14 & 26.99 & 28.83 & 30.68 & 32.53 & 34.38 & 36.23 & 38.08 & 39.92 \\
\hline NISSAN LEAF & 27.66 & 28.33 & 29.00 & 29.66 & 30.33 & 31.00 & 31.66 & 32.33 & 32.99 \\
\hline Hyundai Ioniq & 26.14 & 27.33 & 28.52 & 29.71 & 30.90 & 32.10 & 33.29 & 34.48 & 35.67 \\
\hline
\end{tabular}

The purchase price of Hyundai Ioniq, excluding the government grant, is a third higher than the price of the Škoda Octavia, but with 60,000 mileage, the total cost is starting to develop in favour of the electric car. The calculations are for guidance only, as amortisation included and the need to replace the battery in electric cars. Car insurance was also not included in the costs. However, the insurance of electric cars is lower than that of conventional cars, because the accident and accident rate is assumed to be higher than that of conventional cars. Also, fuel costs vary depending on the method of charging, driving and individual car models. In the following figure we can see how the total costs of individual cars develop. 


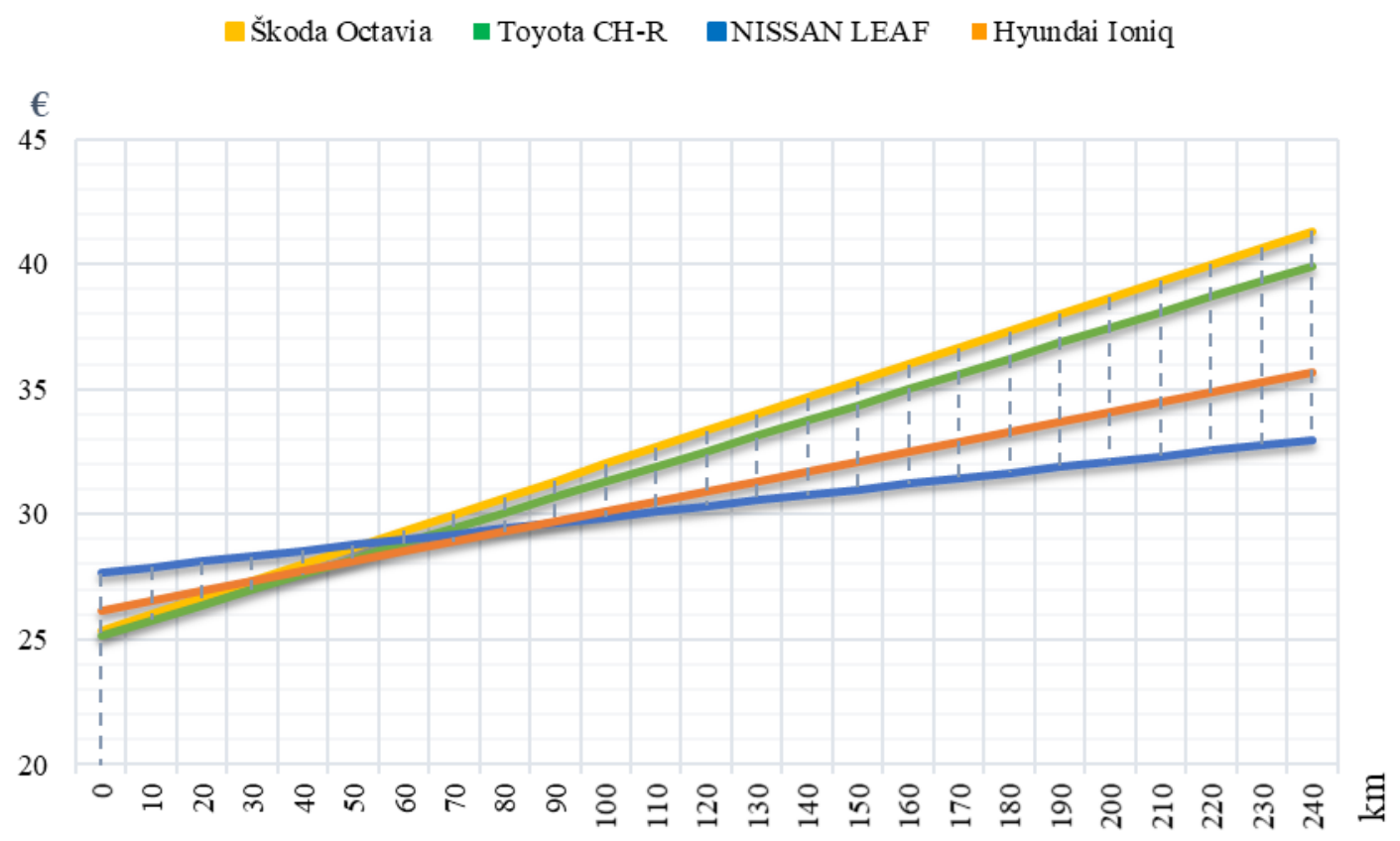

Fig. 2 TCO of selected models. Source: authors

\section{Discussion}

The biggest barrier when buying electric cars is the purchase price. This price can be reduced through mass production and investment in battery development. Through the development of batteries, longer life, performance, lower cost and thus the overall cost of electric cars would be achieved. The batteries are constantly being improved. According to the latest studies, the degradation of the battery is surprisingly low after 8 years. Battery capacity degrades in a non-linear manner. At first, there is a more significant decline, with increasing years, the rate of degradation slows down. However, we are of the opinion that even after replacing the battery, an electric car would be a more cost-effective alternative.

We also are of the opinion that society should be made more aware of the lower total cost of ownership of electric cars compared to conventional cars. In this article, we made this comparison through Total Cost of Ownership (TCO). Within the TCO, we analysed four types of cars: the electric car, the hybrid car, the plug-in hybrid and the standard petrol car. As the result, it was found that the total cost of electronic cars is lower, despite their higher purchase price. The total cost of electric cars with increasing mileage is becoming more cost-effective. The high operating costs of electric cars are manifested only in the first years. After driving certain kilometres, the electric car becomes by far the best economic alternative, but the calculations are only indicative and can be distorting. The number of kilometres at which the total costs of conventional cars and electric cars are offset varies, with the height of kilometres ranging from 50,000 km to $130,000 \mathrm{~km}$. The main reasons for the differences in the calculations are, in particular, the non-inclusion of grants, amortisation, depreciation and battery replacement in electric cars, which form a substantial part of 
the costs. The amount of total costs is mainly affected by fuel costs, which vary depending on the market of oil and renewable energy sources, the way of driving and charging of individual car models.

\section{Conclusion}

The main aim of the article was to explain the terms related to electromobility through the literature and then to examine the total cost of electric cars and conventional cars. The TCO included all estimated costs during the use of individual car types such as purchase price, grants, taxes, maintenance costs and fuel costs. The comparison was made on the example of the best-selling four selected models: electric car, hybrid car, plug-in hybrid car and standard petrol car. The reason for selecting the given cars was because we wanted to point out the costs of the best-selling cars of individual brands. Of course, if we choose a different type of cars, the results would be divergent, but not significantly different, they would be similar. The result of the main aim was the finding that the total costs of electronic cars are lower, despite their higher purchase price. The total cost of electric cars with increasing mileage is becoming more cost-effective. The high operating costs of electric car are manifested only in the first years. After driving certain kilometres, the electric car becomes unrivalled as the most economically advantageous alternative.

\section{Acknowledgments}

The article is a partial output of VEGA No. 1/0375/20 research project titled „New dimension in the development of production management and logistics under the influence of Industry 4.0 in enterprises in Slovakia“.

\section{References}

[1] Fanti, M.P., et al. (2017). Actors interactions and needs in the European electromobility network. In Proceedings of the 2017 International Conference on Service Operations and Logistics, and Informatics, 18-20 September 2017 (pp. 162-167). Bari, Italy.

[2] Benveniste, G., et al. (2018). Comparison of the State of Lithium-Sulphur and Lithium-Ion Batteries Applied to Electromobility. Journal of Environmental Management 226, 1-12. DOI: 10.1016/j.jenvman.2018.08.008.

[3] Altenburg, T., et al. (2015). The Emergence of Electromobility: Comparing Technological Pathways in France, Germany, China and India. Science and Public Policy 43(4), 464-475.

[4] Donada, C. \& Lepoutre, J. (2016). How Can Startups Create the Conditions for a Dominant Position in the Nascent Industry of Electromobility 2.0? International Journal of Automotive Technology and Management 16(1), 11. DOI: 10.1504/ijatm.2016.076444.

[5] Chan, C. C. (2007). The State of the Art of Electric, Hybrid, and Fuel Cell Vehicles. Proceedings of the IEEE 95(4), 704-718. DOI: 10.1109/jproc.2007.892489.

[6] Auvinen, H., et al. (2016). Electromobility Scenarios: Research Findings to Inform Policy. Transportation Research Procedia 14, 2564-2573. DOI 10.1016/j.trpro.2016.05.346. 
[7] Wappelhorst, S., et al. (2014). Potential of Electric Carsharing in Urban and Rural Areas. Transportation Research Procedia 4, 374-386. DOI: 10.1016/j.trpro.2014.11.028.

[8] Qi, X., et al. (2018). Data-Driven Decomposition Analysis and Estimation of Link-Level Electric Vehicle Energy Consumption under Real-World Traffic Conditions. Transportation Research Part D: Transport and Environment 64, 36-52. DOI: 10.1016/j.trd.2017.08.008.

[9] Bubeck, S., et al. (2016). Perspectives of Electric Mobility: Total Cost of Ownership of Electric Vehicles in Germany. Transport Policy 50, 63-77. DOI: 10.1016/j.tranpol.2016.05.012.

[10] Tucki, K, et al. (2019). The Development of Electromobility in Poland and EU States as a Tool for Management of CO2 Emissions. Energies 12(15), 2942. DOI: 10.3390/en12152942.

[11] Palmer, K., et al. (2018). Total Cost of Ownership and Market Share for Hybrid and Electric Vehicles in the UK, US and Japan. Applied Energy 209, 108-119. DOI: 10.1016/j.apenergy.2017.10.089.

[12] Ellram, Lisa M. (1995). Total Cost of Ownership. International Journal of Physical Distribution \& Logistics Management 25(8), 4-23. DOI: 10.1108/09600039510099928.

[13] Bickert, S., et al. (2015). Developments of CO2-Emissions and Costs for Small Electric and Combustion Engine Vehicles in Germany. Transportation Research Part D: Transport and Environment 36, 138-151. DOI: 10.1016/j.trd.2015.02.004.

[14] Redelbach, M., et al. (2012). Competitive Cost Analysis of Alternative Powertrain Technologies. In Conference Programme IAMF 2012. International Advanced Mobility Forum 2012 (IAMF), 07.-08. Mrz. 2012, Genf, Schweiz.

[15] Danielis, R., et al. (2020). The Economic Case for Electric Vehicles in Public Sector Fleets: An Italian Case Study. World Electric Vehicle Journal 11(1), 22. DOI: 10.3390/wevj11010022.

[16] Figenbaum, E., et al. (2013). Electromobility in Norway : Experiences and Opportunities with Electric Vehicles. Oslo: Transportøkonomisk Institutt.

[17] Lebeau, K., et al. (2013). How Expensive Are Electric Vehicles? A Total Cost of Ownership Analysis. World Electric Vehicle Journal 6(4), 996-1007. DOI: 10.3390/wevj6040996.

[18] Nissan. (2020, September). Nový Nissan Leaf, úspory a výhody. Retrieved September, 20, 2020, from https://www.nissan.sk/vozidla/nove-vozidla/leaf/uspora-a-vyhody.html

[19] Hyundai. (2020, September). Hyundai Ioniq Electric. Retrieved September, 21, 2020, from https://www.hyundai.sk/modely/ioniq-electric

[20] Toyota. (2020, September). Toyota C-HR Style. Retrieved September, 22, 2020, from https://www.toyota.sk/new-cars/c-hr/

[21] Skoda-Auto. (2020, September). Cenník nová Škoda Octavia. Nový Nissan Leaf, úspory a výhody. Retrieved September, 22, 2020, from http://dealer.skodaauto.sk/SiteCollectionDocuments/cenniky/skoda_octavia_facelift_cennik.pdf

[22] Štatistický úrad Slovenskej republiky. Ceny pohonných hmôt. Retrieved September, 22, 2020, from http://statdat.statistics.sk/cognosext/cgibin/cognos.cgi?b_action=xts. 